\title{
Audit Quality And Accrual Reliability: Evidence From The Korean Stock Market
}

\author{
Jong Eun Lee, SungKyunKwan University, South Korea
}

\begin{abstract}
This study empirically investigates whether a high-quality audit improves the reliability of the components of total accruals using earnings persistence and cash flow predictability. I find that, for firms audited by Big Four auditors, their current or noncurrent assets-related accruals, which are less reliable ("more subjective in measurement"), lead to higher earnings persistence and future cash flow predictability than those of firms audited by non-Big Four auditors. These results suggest that high-quality auditors more effectively evaluate the reasonableness of accrual measurement based on more sufficient and appropriate audit evidence, leading to enhanced accrual reliability.
\end{abstract}

Keywords: Audit Quality; Accrual Reliability; Accounting Estimates

\section{INTRODUCTION}

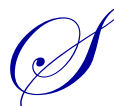

tatement of Financial Accounting Concepts (SFAC) No. 8 states that the purpose of financial reporting is to provide stakeholders with useful information about a company to help them make their financial decisions (FASB 2010). ${ }^{1}$ To be useful, the information should have two fundamental qualitative characteristics: relevance and faithful representation (i.e., reliability). The tradeoff between relevance and reliability has long been hotly debated among standard-setters, regulators, and academics.

Since the enactment of the 2002 Sarbanes-Oxley Act (SOX) and the 2011 adoption of the International Financial Reporting Standards (IFRS), the financial reporting paradigm has moved toward more principles-based accounting, which focuses on the relevance of accounting information rather than its reliability. ${ }^{2}$ Accordingly, the mainstream of standard-setting has changed to fair value accounting and accounting estimates, the estimation processes of which are more subjective. Reported accruals are expected to be more likely to have estimation errors owing to noise caused by estimation subjectivity, which reduces accrual reliability. In discussing accrual reliability, regulators, academics, and accounting and auditing professionals have been debating how the reliability of accounting information can be enhanced, emphasizing the importance of external auditors (PCAOB, 2007). ${ }^{3}$ Focusing on accounting estimates-related accruals, I investigate external auditors' role in enhancing accrual reliability, measured as accrual persistence or cash flow predictability, using public Korean companies listed on the KOSDAQ (Korean Securities Dealers Automated Quotations).

It has been shown that accruals are less persistent than are cash flows for future performance (Sloan, 1996; Barth et al., 1999), primarily because of the inherent subjectivity embedded in accrual measurement (Bernstein, 1993; Sloan, 1996; Barth et al., 1999). This subjectivity, as linked to accrual reliability, leads to accrual measurement error ("estimation error"), which provides noise for future earnings prediction (Richardson et al., 2005; Dechow and Dichev, 2002). Further, while accruals are useful for predicting firms' future cash flows (Statement of Financial Accounting Concepts No.1, 1978), their usefulness can be reduced through accrual measurement error, which lowers the predictability of accruals relative to cash flows. Specifically, accounting estimates such as allowances for

\footnotetext{
${ }^{1}$ The Financial Accounting Standard Board (FASB) issued FASB Concepts Statement No. 8 in September 2010 to replace FASB Concepts Statements No. 1 and No. 2.

${ }^{2}$ Following the SEC (2003) report, principles-based accounting is defined as objective-oriented accounting, characterized as balance sheetoriented accounting requiring more professional judgment to better represent the economic substance of transactions.

${ }^{3}$ During a Compliance Week Annual Conference on Governance, Risk \& Compliance in Washington, DC, former PCAOB chairman Mark Olson expressed concerns about auditors' readiness to audit fair value accounting (i.e., FAS 159, Fair Value Option for Financial Assets and Liabilities). He also said, "The increased use of fair value accounting poses a challenge for auditors and the PCAOB" (2007).
} 
doubtful receivables, asset write-downs, goodwill impairments, adjustments in pension liabilities, and fair value estimates on management compensation are virtually inevitable in the accrual-basis financial reporting system, and the accountability of these estimates has long been a concern to regulators, standard setters, and academics because of their inherent subjectivity and the potential for management's opportunistic reporting (Levitt, 1998; Ramos, 1998; Kinney, 2001).

Richardson et al. (2005) go beyond the comparison of accrual persistence to cash flow persistence and decompose total accruals into seven types according to the level of estimation subjectivity using a balance sheet approach and investigate the predictability of current-year accruals with different levels of estimation subjectivity on one-yearahead earnings. Richardson et al. (2005) report that current assets and noncurrent assets or liabilities-related accruals are less persistent for future earnings performance than are current liabilities-related accruals owing to the relatively high degree of estimation error caused by the relatively high level of inherent subjectivity ("less reliable") in the measurement of accounting estimates embedded in current and noncurrent assets (liabilities). Furthermore, along with the adoption of IFRS, standard setters' recent move toward a more principles-based accounting system has unintentionally but substantially increased the implementation of accounting estimates, suggesting that overall accrual reliability is more challenged by the increase in accrual measurement error (Schipper, 2003; Lev et al., 2010; Christensen et al., 2012).

The potential reduction of accrual reliability through a change in financial reporting paradigm could turn regulators' attention to the auditing profession. First, the importance of external auditors as monitoring devices for financial reporting is growing. ${ }^{4}$ Related to the inherent subjectivity of accrual measurement, management's discretionary judgment may exacerbate agency problems among stakeholders through enhanced information asymmetry (DeFond, 1992; Francis and Krishnan, 1999). Furthermore, the downgrading of verifiability as a key reporting concept under the new reporting regime is leading to doubts about the reliability of reported accruals. Investors expect external auditors to reduce agency problems and provide information users with more reliable accruals for firm performance prediction. Second, the auditing profession has been held accountable for evaluating the reasonableness of management's accrual measurement process. Concerning accounting estimates, while Korean Auditing Standard Section 540 prescribes that, while management is primarily responsible for reported accounting estimates, auditors are responsible for evaluating the reasonableness of the accounting estimates made by management and the appropriateness of related disclosures. ${ }^{5}$ Thus, auditors still bear a litigation risk, which could be triggered by intentional or unintentional management bias and the estimation uncertainty involved in accounting estimates (Baron et al., 2004). ${ }^{6}$

Motivated by the remarkable adoption of principles-based accounting into the financial reporting system and the importance of external auditors, I investigate whether a high-quality audit enhances accrual reliability. If a highquality audit can minimize biases by competently evaluating the reasonableness of the assumptions of reported accruals (e.g., Becker et al., 1998; Krishnan, 2003a, 2003b), I expect that a high-quality audit will produce more reliable accruals and thus lead to higher earnings persistence and cash flow predictability by reducing accrual measurement or future correction error (e.g., Dechow and Dichev, 2002; Richardson et al., 2005). Consistent with this prediction, I find that, for firms audited by Big Four auditors, highly subjective accrual components such as current and noncurrent assets-related accruals, which are less reliable ("more subjective in measurement"), have higher one-year-ahead earnings persistence than those of firms audited by non-Big Four auditors. I also find that the highly subjective accrual components of firms audited by high-quality auditors are more predictive of one-yearahead cash flows. Moreover, for low-subjectivity accrual components such as current liabilities, short-term investments, and financial liabilities-related accruals, which are more reliable ("more objective in measurement"), I

\footnotetext{
${ }^{4}$ The Public Company Accounting Oversight Board (PCAOB) issued Staff Audit Practice Alert No. 3, "Audit considerations in the current economic environment" (2008), to point out the potentially critical audit areas auditors should focus on when auditing public companies during an economic downturn. One of the six audit areas is accounting estimates. The others are fraud risk, fair value measurements, management representations, the adequacy of disclosures, and the going concern issue. The PCAOB also issued Alert No. 7, "Audit considerations of litigation and other contingencies arising from mortgage and other loan activities" (2010), to remind auditors to evaluate the reasonableness of accounting estimates such as accruals or reserves for mortgage-related contingencies, especially focusing on publicly held financial institutions.

${ }^{5}$ The interim Auditing Standard AU 342 of the Public Company Accounting Oversight Board similarly outlines auditors' responsibilities relating to audits of accounting estimates.

${ }^{6}$ In addition, concerning the auditing of internal control over financial reporting under Section 404 of SOX, AS No. 5, paragraph 14 (PCAOB) requires auditors to evaluate whether the client has adequate controls to address the risk related to "significant management estimates."
} 
consistently find the same results for one-year-ahead earnings persistence and cash flows. Overall, these results imply that high-quality auditors more effectively evaluate the reasonableness of the measurement assumptions of highly subjective accruals as well as less subjective accruals based on more sufficient and appropriate audit evidence, thus reducing measurement error for accruals and enhancing accrual reliability.

My study contributes to the relevant research stream in several ways. First, focusing on total accruals (including noncurrent accruals), I empirically examine the association between accrual reliability and audit quality, using earnings persistence and cash flow predictability. This study of earnings management focuses on management opportunistic behavior using discretionary accruals, which have been used in most of the studies on the associations between audit quality and financial reporting quality. As documented in Dechow and Dichev (2002), the opportunistic use of accruals can reduce earnings persistence by intentionally creating noise such as accrual measurement error. Meanwhile, nondiscretionary accruals have received little research attention. Richardson et al. (2005) call for an examination of noncurrent accruals, finding that noncurrent accruals included in nondiscretionary accruals negatively but unintentionally affected earnings persistence owing to accrual measurement error caused by an inherently low degree of reliability. Thus, this study argues that accrual reliability is not confined to discretionary accruals but extends to total accruals, including nondiscretionary accruals. I reshuffle total accruals and classify them into seven categories (e.g., changes in current or noncurrent assets, or liabilities) in accordance with the balance sheet approach in Richardson et al. (2005). As documented in Richardson et al. (2005), each of the seven accrual components of earnings has a different level of accrual reliability, an important issue given that the current financial framework, with its emphasis on the balance sheet model, has substantially increased the use of accounting estimates (Lev et al., 2010). Second, the prior literature has paid little attention to the role of external auditors in improving the reliability of noncurrent accruals. My study addresses this issue by investigating the association between audit quality and the reliability of each accrual component of total accruals, including current and noncurrent accruals. Amid the change of financial reporting paradigm to more principles-based accounting standards, my study sheds light on the relationship between the reliability of accruals (including accounting estimates) and the role of external auditors, a pressing issue of interest to the auditing profession, academia, and regulators.

The remainder of this paper is organized as follows. Section II reviews the literature and develops the hypotheses. Section III discusses the paper's research design, including the measurement of variables. Section IV reports the descriptive statistics of the sample. Section V presents the results of multivariate analyses. Finally, a summary and conclusion are presented in Section VI.

\section{PRIOR LITERATURE AND HYPOTHESIS DEVELOPMENT}

\section{Accounting Estimates and Accrual Reliability}

Unlike cash-basis accounting, accrual-basis accounting requires "assumptions and estimates of future cash flows" for accrual measurement (Dechow and Dichev, 2002). While the accuracy of the assumptions and estimates is negatively associated with accrual measurement errors and/or future correction errors, I expect that a certain level of measurement error is unavoidable owing to the subjectivity of the accrual measurement process; the prevalence of accounting estimates and projections, a crucial part of accrual-basis accounting, could worsen measurement error. The pervasiveness of accounting estimates depends on the nature of the particular transactions or changes in the economy and the applicable financial reporting framework. As the balance sheet-based reporting model has become the norm in financial reporting, the FASB has gradually and widely incorporated accounting estimates for a better valuation of assets and liabilities in financial reporting. ${ }^{7,8}$ The Korean Accounting Standards Board (KASB) has moved in the same direction as the FASB and IASB. Furthermore, the accounting literature expects that accounting

\footnotetext{
${ }^{7}$ Moreover, the recent move by standard setters toward fair value accounting, including hedging accounting in 1999 (former SFAS No.133), business combination and goodwill accounting in 2001 (former SFAS No.141 and former SFAS No.142, respectively), pension accounting in 2003 (former SFAS No. 132), and asset securitization in 2005 (former SFAS No.156), leads to a substantial increase of reported accounting estimates in financial reporting.

${ }^{8}$ The International Auditing and Assurance Standards Boards (IAASB) issued a Staff Audit Practice Alert (October 2008) expressing the expected increase in accounting estimates, particularly fair value estimates, and highlighting the challenges that audit professionals face in auditing fair value estimates during times of market uncertainty.
} 
estimates in financial reporting will be more pervasive under the new U.S. financial reporting framework with convergence to IFRS (e.g., Schipper, 2003; Dichev, 2008; Lev et al., 2010; Christensen et al., 2012). Eventually, the pervasiveness of accounting estimates will reduce accrual reliability, in turn reducing the usefulness of earnings' accrual components in predicting firm performance.

Thus, in response to the prevalence of accounting estimates in financial reporting, regulators and academics have raised mounting concerns, mainly owing to the inherent subjectivity of accounting estimates and consequent loss of verifiability. The primary concerns are the potential increase in management's opportunistic reporting and litigation risk to auditors, as well as the readiness of auditors to audit fair value accounting, including accounting estimates (Schipper, 2003; PCAOB, 2007; Jamal et al., 2010).

\section{Audit Quality and Accrual Reliability}

The importance of auditors as external monitoring devices for firms' financial reporting has received significant attention from regulators and standard setters. There is a general consensus on the significant contribution auditors make to the capital markets.

Although the role of accounting estimates in financial reporting to compute earnings and their impact on accrual reliability is crucial, there is scant empirical evidence regarding the association between accrual reliability and external auditing from the perspective of accounting estimates.

A number of studies have documented the association between audit quality (i.e., Big $\mathrm{N}$ vs. non-Big $\mathrm{N}$ auditors) and financial reporting quality, such as discretionary accruals, going concern opinions, and SEC enforcement. Most show that Big N auditors have lower discretionary accruals (Becker et al., 1998; Francis et al., 1999; Choi et al., 2010) and a lower threshold for issuing going concern opinions (Francis and Krishnan, 1999) and are less sanctioned by the SEC (St. Pierre and Anderson, 1984; Palmrose, 1988; Feroz et al., 1991). When I narrow the scope of prior studies down to the issue of accrual reliability (including accounting estimates), the relevant studies become fewer. For instance, Petroni and Beasely (1996) directly focus on accounting estimates of claim loss reserves in 197 property-casualty insurers from 1979 to 1983 , but they find no significant role difference between Big Eight audit firms and non-Big Eight audit firms regarding the accuracy of claim loss reserves, suggesting that Big Eight audit firms do not significantly enhance reserve reliability.

In this study, I posit that high-quality auditors minimize the inherent biases in the measurement of accounting estimates embedded in each accrual component by competently evaluating their reasonableness and thereby improve accrual reliability.

To empirically test whether a high-quality audit produces more reliable accruals, I focus on the persistence of each of the disaggregated accrual components of total accruals in predicting one-year-ahead earnings and cash flows. As is clearly addressed in the Statement of Financial Accounting Concepts No. 1 (FASB 1978) and in the literature (e.g., Dechow et al., 1998; Richardson et al., 2005), accruals are useful in projecting future performance. Their usefulness depends on accrual reliability, which is negatively correlated with measurement error. In this study, I expect that a high-quality audit will improve accrual reliability by reducing the measurement errors embedded in accruals. The measurement errors reduce earnings persistence and cash flow predictability as noise for future performance prediction. Furthermore, the consequence of a high-quality audit will be expressed as an enhanced power to predict future performance such as earnings and cash flows.

As Richardson et al. (2005) point out, however, components of total accruals have different levels of inherent measurement subjectivity. For example, accruals related to current assets such as accounts receivable or inventory are likely to have more estimation errors than those related to current liabilities such as accounts payable or taxes payable because current asset-related accruals include more accounting estimates, such as allowances for doubtful accounts or inventory valuations. The accounting estimates embedded in current asset-related accruals create noise for future performance prediction, lowering accrual reliability. Given the role of external auditors in improving accrual reliability, I conjecture that high-quality audits will be more effective in improving the reliability of accruals that include more accounting estimates with higher managerial subjectivity. Meanwhile, I expect no significant 
difference between low- and high-quality audits in improving the reliability of accruals that include more accounting estimates with lower managerial subjectivity. Therefore, I hypothesize as follows (stated in alternative form):

H: High-quality audits are more likely to be effective in improving the reliability of accruals that include more accounting estimates with higher management subjectivity.

\section{MEASUREMENT AND RESEARCH DESIGN}

\section{Components of Total Accruals}

Building on Richardson et al. (2005), I decompose the balance sheet to better gauge accruals related to noncurrent operating activities (e.g., noncurrent assets and noncurrent liabilities). Richardson et al. (2005) decompose total accruals into seven different types using the balance sheet approach. I rewrite the decomposition of total accruals as follows:

$$
A C C=\triangle C O A+\triangle N C O A-\triangle N C O L+\triangle L T I+\triangle S T I-\triangle C O L-\triangle F I N L
$$

Then, I group seven accrual components in Eq. (1) into three categories based on the degree of reliability, determined by how many types of accounting estimates with high estimation subjectivity are included in each of the accrual components. First, both $\triangle C O A$ and $\triangle N C O A$ include several types of accounting estimate, such as the estimation of uncollectible receivables, impairments of long-lived assets, goodwill impairments, and stock compensation, which lower accrual reliability. The sum of $\triangle C O A$ and $\triangle N C O A$ is classified as "high subjective accrual component." Second, both $\triangle N C O L$ and $\triangle L T I$ include both high and low estimation subjectivity, such as long-term payables, postretirement benefit obligations, long-term receivables, and long-term investment in marketable securities. The sum of $-\triangle N C O L$ and $\triangle L T I$ is classified as "other accrual component" because each of the two components has a variety of accrual types with different levels of managerial subjectivity, making classification into a specific category difficult." Finally, the sum of $-\triangle C O L, \triangle S T I$, and $-\triangle F I N L$ is classified as "low subjective accrual component," which includes a low degree of estimation subjectivity such as accounts payable, taxes payable, and short-term investment.

I thus classify seven accrual components in Eq. (1) into three categories as follows:

High Subjective Accrual Component $(H i g h S u b j A c c r)=\triangle C O A+\triangle N C O A$

Other Accrual Component (OtherAccr) $=-\triangle N C O L+\triangle L T I$

Low Subjective Accrual Component (LowSubjAccr $)=-\triangle C O L+\triangle S T I-\triangle F I N L$

\section{Research Design}

I test the study's hypothesis using the regression model below:

$$
\begin{aligned}
\text { FROA }_{i t} & =\omega_{0}+\omega_{1} \text { BIG4 }+\omega_{2} \text { HighSubjAccr }+\omega_{3} \text { OtherAccr }+\omega_{4} \text { Low SubjAccr } \\
& +\omega_{5} B I G 4 * \text { HighSubjAccr }+\omega_{6} B I G 4 * \text { OtherAccr }+\omega_{7} \text { BIG } 4 \text { LowSubjAccr } \\
& +\omega_{8} \text { CFO }+ \text { CTRL }+\varepsilon_{i t}
\end{aligned}
$$

In Eq. (5), I expect a positive coefficient $\left(\omega_{5}>0\right)$ on the interaction term if the high-quality audit leads to a higher persistence of HighSubjAccr ( $\triangle C O A$ and $\triangle N C O A$ ) with more accounting estimates by reducing measurement error. While a high-quality audit is also expected to improve the reliability of LowSubAccr (- $\triangle C O L, \triangle S T I,-\triangle F I N L)$ with less accounting estimates, it is difficult to say whether the effect of a high-quality audit on the reliability of those

\footnotetext{
${ }^{9}$ Richardson et al. (2005) classified $-\triangle N C O L$ and $\triangle L T I$ as medium-level accrual components.
} 
accruals is statistically significant given that it is easier for external auditors to audit accruals with fewer accounting estimates.

I include several variables in the regression model to control for factors influencing earnings persistence. Following the literature (e.g., Simunic and Stein, 1987; DeFond, 1992; Francis et al., 1999), I control for a firm's leverage (LEV), measured as total liabilities divided by total assets. I also control for total assets (ASSET) and loss (LOSS) to consider the different effects of a firm's size and negative performance. Finally, I add year-dummy and industrydummy variables (using the two-digit SIC code) to control for fixed-year effects and industry. The definitions of our control variables appear in the appendix.

\section{SAMPLE AND DESCRIPTIVE STATISTICS}

\section{Sample Selection}

I obtain financial and external auditor data from KIS-Value. To avoid confounding the effects of the SOX on financial reporting in Korean capital markets, I collect data covering 2003 to 2012. From the initial sample, I exclude observations in regulated industries such as the utilities and financial industries because of their different operating outcomes. The sample is limited to firms with a December fiscal year-end to maintain homogeneity regarding auditors' busy month. ${ }^{10} \mathrm{I}$ also exclude observations that lack necessary financial or external auditors. The final sample consists of 7,493 firm-year observations.

\section{Descriptive Statistics}

Table 1 presents the characteristics of the sample firms' key variables. All continuous variables are deflated by average total assets. Table 1 shows that the mean of each variable (i.e., $\triangle C h C O A, \triangle C h N C O A, \triangle C h S T I, \triangle C h L T I$, $\triangle C h F I N L)$, except for $\triangle C h C O L$ and $\triangle C h N C O L$, is greater than its median, indicating that each variable has positively skewed distribution and is generally an income-decreasing accrual. HighSubjAccr (mean value $=0.073$ ) takes a large portion of total accruals relative to the other two accrual components of OtherAccr (mean value $=0.000$ ) and LowSubjAccr (mean value $=-0.015$ ). Of the 7,493 firm-year observations, $42.7 \%$ (mean value of BIG4 $=0.427$, $\mathrm{n}=3,200)$ are audited by Big Four auditors. The mean (median) values of the sample firms' profitability $(F R O A)$ is $0.064(0.020)$. The negative skewed distribution of FROA can be attributed to the inclusion of a recessionary segment (2007-2009) in the testing period. Of the sample, 35.2\% (mean value of LOSS $=0.352$ ) has negative net income. The mean (median) value of the natural log of total assets (LOGTA) is 24.820 (24.801).

\footnotetext{
${ }^{10}$ As a sensitivity analysis, I re-estimated the regression in the table for the sample without placing a limitation on the fiscal year-end. The results are unchanged. 
Table 1. Descriptive Statistics of Key Variables

\begin{tabular}{l|r|r|r|r|r|r|r}
\hline \multicolumn{1}{c|}{ Variable } & Mean & Median & Std. Dev & $\mathbf{5 \%}$ & $\mathbf{2 5 \%}$ & $\mathbf{7 5 \%}$ & $\mathbf{9 5 \%}$ \\
\hline TACC & 0.058 & 0.057 & 0.259 & -0.310 & -0.036 & 0.154 & 0.431 \\
\hline$\Delta$ ChCOA & 0.025 & 0.018 & 0.151 & -0.192 & -0.034 & 0.081 & 0.258 \\
\hline$\Delta$ ChCOL & -0.015 & -0.008 & 0.112 & -0.171 & -0.048 & 0.024 & 0.119 \\
\hline$\Delta$ ChNCOA & 0.048 & 0.023 & 0.200 & -0.212 & -0.020 & 0.100 & 0.363 \\
\hline$\Delta$ ChNCOL & -0.003 & -0.001 & 0.031 & -0.030 & -0.007 & 0.004 & 0.023 \\
\hline$\Delta$ ChSTI & 0.005 & 0.000 & 0.111 & -0.149 & -0.028 & 0.032 & 0.174 \\
\hline$\Delta$ ChLTI & 0.003 & 0.000 & 0.088 & -0.096 & -0.012 & 0.014 & 0.112 \\
\hline$\Delta$ ChFINL & 0.005 & 0.000 & 0.113 & -0.140 & -0.015 & 0.017 & 0.170 \\
\hline HighSubjAccr & 0.073 & 0.058 & 0.271 & -0.310 & -0.039 & 0.177 & 0.494 \\
\hline OtherAccr & 0.000 & -0.001 & 0.092 & -0.107 & -0.020 & 0.017 & 0.114 \\
\hline LowSubjAccr & -0.015 & -0.010 & 0.192 & -0.298 & -0.093 & 0.065 & 0.257 \\
\hline BIG4 & 0.427 & 0.000 & 0.495 & 0.000 & 0.000 & 1.000 & 1.000 \\
\hline FROA & -0.064 & 0.020 & 0.386 & -0.593 & -0.081 & 0.072 & 0.189 \\
\hline FCFO & 0.022 & 0.032 & 0.229 & -0.261 & -0.040 & 0.108 & 0.258 \\
\hline CFO & 0.022 & 0.032 & 0.159 & -0.213 & -0.036 & 0.102 & 0.226 \\
\hline LEV & 0.429 & 0.418 & 0.305 & 0.094 & 0.250 & 0.571 & 0.786 \\
\hline LOSS & 0.352 & 0.000 & 0.478 & 0.000 & 0.000 & 1.000 & 1.000 \\
\hline LOGTA & 24.820 & 24.801 & 0.944 & 23.000 & 24.000 & 25.000 & 27.000 \\
\hline No, of Obs & 7,493 & & & & & &
\end{tabular}

No. of Obs.

7,493

This table reports the descriptive statistics of key variables from 2003 to 2012 (For FROA, from 2004 to 2013). The variable measurements are summarized in the appendix.

Table 2 reports the Pearson correlations between the key variables of the sample observations and three accrual groups by managerial subjectivity. HighSubjAccr is positively correlated with FROA (correlation=0.015) but not significantly, and OtherAccr and LowSubjAccr are negatively and significantly correlated with FROA. HighSubjAccr is positively and significantly correlated with $F C F O$ (correlation $=0.072$, p-value $=<.0001)$. LOGTA is positively and significantly correlated with HighSubjAccr (correlation $=0.211$, p-value $=<.0001$ ) and OtherAccr (correlation $=0.047$, p-value $=<.0001$ ) but negatively and significantly correlated with LowSubjAccr (correlation=0.057 , p-value $=<.0001)$.

Table 2. Correlation Analysis

\begin{tabular}{|c|c|c|c|c|c|c|c|c|}
\hline Variables & $T A C C$ & $\begin{array}{c}\text { HighSubjA } \\
\text { ccr }\end{array}$ & $\begin{array}{l}\text { Other } \\
\text { Accr }\end{array}$ & $\begin{array}{c}\text { LowSubj } \\
\text { Accr }\end{array}$ & BIG4 & FROA & FCFO & $\mathrm{CFO}$ \\
\hline \multicolumn{9}{|l|}{$T A C C$} \\
\hline $\begin{array}{l}\text { HighSubj } \\
\text { Accr }\end{array}$ & $\begin{array}{c}0.686 \\
(<.0001)\end{array}$ & & & & & & & \\
\hline $\begin{array}{l}\text { Other } \\
\text { Acccr }\end{array}$ & $\begin{array}{c}0.182 \\
(<.0001)\end{array}$ & $\begin{array}{l}-0.148 \\
(<.0001)\end{array}$ & & & & & & \\
\hline $\begin{array}{l}\text { LowSubj } \\
\text { Accr }\end{array}$ & $\begin{array}{c}0.298 \\
(<.0001)\end{array}$ & $\begin{array}{l}-0.414 \\
(<.0001)\end{array}$ & $\begin{array}{l}-0.024 \\
(0.038)\end{array}$ & & & & & \\
\hline$B I G 4$ & $\begin{array}{c}0.005 \\
(0.644)\end{array}$ & $\begin{array}{c}0.009 \\
(0.454)\end{array}$ & $\begin{array}{l}-0.003 \\
(0.772)\end{array}$ & $\begin{array}{l}-0.003 \\
(0.770)\end{array}$ & & & & \\
\hline FROA & $\begin{array}{l}-0.018 \\
(0.130)\end{array}$ & $\begin{array}{c}0.015 \\
(0.201)\end{array}$ & $\begin{array}{l}-0.031 \\
(0.008)\end{array}$ & $\begin{array}{l}-0.030 \\
(0.010)\end{array}$ & $\begin{array}{c}0.095 \\
(<.0001)\end{array}$ & & & \\
\hline$F C F O$ & $\begin{array}{c}0.071 \\
(<.0001)\end{array}$ & $\begin{array}{c}0.072 \\
(<.0001)\end{array}$ & $\begin{array}{l}-0.034 \\
(0.004)\end{array}$ & $\begin{array}{c}0.010 \\
(0.379)\end{array}$ & $\begin{array}{c}0.074 \\
(<.0001)\end{array}$ & $\begin{array}{c}0.501 \\
(<.0001)\end{array}$ & & \\
\hline$C F O$ & $\begin{array}{l}-0.014 \\
(0.224)\end{array}$ & $\begin{array}{c}0.020 \\
(0.076)\end{array}$ & $\begin{array}{l}-0.045 \\
(0.0001)\end{array}$ & $\begin{array}{l}-0.027 \\
(0.021)\end{array}$ & $\begin{array}{c}0.116 \\
(<.0001)\end{array}$ & $\begin{array}{c}0.397 \\
(<.0001)\end{array}$ & $\begin{array}{c}0.408 \\
(<.0001)\end{array}$ & \\
\hline$L O G T A$ & $\begin{array}{c}0.196 \\
(<.0001)\end{array}$ & $\begin{array}{c}0.211 \\
(<.0001)\end{array}$ & $\begin{array}{c}0.047 \\
(<.0001)\end{array}$ & $\begin{array}{l}-0.057 \\
(<.0001)\end{array}$ & $\begin{array}{c}0.238 \\
(<.0001)\end{array}$ & $\begin{array}{c}0.268 \\
(<.0001)\end{array}$ & $\begin{array}{c}0.207 \\
(<.0001)\end{array}$ & $\begin{array}{c}0.262 \\
(<.0001)\end{array}$ \\
\hline
\end{tabular}

This table shows the Pearson correlation coefficients of key variables. See the appendix for variable definitions (p-values are shown in italics below the correlations) 


\section{EMPIRICAL RESULTS}

\section{Univariate Analysis}

The results of the univariate analysis are presented in Table 3. Overall, key attributes such as accrual components (except for $\triangle C h S T I$ ) do not differ significantly between firms audited by Big Four auditors and those audited by non-Big Four auditors. Moreover, HighSubjAccr, OtherAccr, and LowSubjAccr do not differ significantly between the two firm types. The future performance $(F R O A$ and $F C F O)$ and cash flows $(C F O)$ of firms audited by Big Four auditors differ significantly from those of firms audited by low-quality auditors. The firms audited by Big Four auditors have lower leverage and are more likely to have positive net income and to be large.

Table 3. Univariate Analysis for Firms Audited by Big Four and non-Big Four Auditors

\begin{tabular}{|c|c|c|c|}
\hline & BIG4 & NON-BIG4 & t-statistics \\
\hline$T A C C$ & 0.059 & 0.056 & 0.48 \\
\hline$\triangle C h C O A$ & 0.026 & 0.024 & 0.74 \\
\hline$\triangle C h C O L$ & -0.015 & -0.015 & -0.02 \\
\hline$\triangle C h N C O A$ & 0.050 & 0.047 & 0.48 \\
\hline$\triangle C h N C O L$ & -0.003 & -0.003 & -0.40 \\
\hline$\Delta C h S T I$ & 0.002 & 0.006 & $-1.65^{*}$ \\
\hline$\Delta C h L T I$ & 0.003 & 0.003 & -0.17 \\
\hline$\triangle C h F I N L$ & 0.003 & 0.006 & -1.15 \\
\hline HighSubjAccr & 0.076 & 0.071 & 0.77 \\
\hline OtherSubjAccr & -0.000 & 0.000 & -0.29 \\
\hline LowSubjAccr & -0.016 & -0.015 & -0.30 \\
\hline FROA & -0.022 & -0.096 & $8.85^{* * *}$ \\
\hline$F C F O$ & 0.041 & 0.007 & $6.79^{* * *}$ \\
\hline$C F O$ & 0.043 & 0.006 & $10.54^{* * *}$ \\
\hline$L E V$ & 0.421 & 0.435 & $-2.09^{* *}$ \\
\hline LOSS & 0.307 & 0.386 & $-7.13^{* * *}$ \\
\hline LOGTA & 25.081 & 24.626 & $20.78^{* * *}$ \\
\hline No. of Obs. & 3,200 & 4,293 & \\
\hline
\end{tabular}

\section{Multivariate Regression Analysis}

For the regression analyses below, the reported statistics and significance levels are based on standard errors adjusted by a one-dimensional cluster at the firm level.

\section{Results on the Reliability of Accounting Estimates}

Table 4 presents the results of the OLS regression analyses testing the hypothesis that a high-quality audit leads to a higher persistence of accrual components with less reliability regarding future earnings owing to the enhanced reliability of the accounting estimates of Big Four auditors. I use signed variables to test the persistence of each of the accrual components, which are classified through the balance sheet approach.

Table 4 shows the results of the regression analysis. As expected, I find that the coefficients of the variables $\left(B I G 4^{*} \triangle C h C O A\right.$ and $\left.B I G 4^{*} \triangle C h N C O A\right)$ of the interaction term of Big Four auditors and each of the accrual components with less reliability are positive and significant at the 10 and $5 \%$ levels, respectively. These results suggest that a high-quality audit improves the reliability of accrual components with less reliability (i.e., $\triangle C h C O A$, $\triangle C h N C O A$ ) by reducing accrual measurement error through the collection and evaluation of more and better audit evidence using competence and professional judgment. In addition, consistent with the finding of Sloan (1996) and Richardson et al. (2005) that accruals (or all accrual components) are, overall, less persistent than the cash component of earning, the coefficient of the variable of operating cash flow is greater than the coefficients of all accrual component variables. I also find that the coefficients of $B I G 4^{*} \triangle C h C O L$ and $B I G 4 * \Delta C h S T I$ are significant at 
the 5 and 10\% levels, respectively, suggesting that Big Four auditors are also effective in auditing accruals components with less managerial subjectivity. Furthermore, I find that the coefficients of the variables $\left(B I G 4^{*} \triangle C h N C O L, B I G 4^{*} \triangle C h L T I, B I G 4^{*} \triangle C h F I N L\right)$ of the Big Four interaction term are positive but not significant.

Table 4. Regression Results on the Effects of Audit Quality on the Persistence of Accruals Components

\begin{tabular}{|c|c|c|c|}
\hline \multirow{2}{*}{ Variable } & \multirow{2}{*}{$\begin{array}{c}\text { Expected } \\
\text { Sign }\end{array}$} & \multicolumn{2}{|c|}{ Dependent Variable: $F R O A$} \\
\hline & & Coefficient & t-Statistics \\
\hline Intercept & $?$ & $-1.511^{* * *}$ & -6.27 \\
\hline$B I G 4$ & $?$ & 0.006 & 0.74 \\
\hline$\triangle C h C O A$ & $?$ & 0.051 & 0.49 \\
\hline$\triangle C h C O L$ & $?$ & 0.054 & 0.27 \\
\hline$\triangle C h N C O A$ & $?$ & $-0.184^{* * *}$ & -4.35 \\
\hline$\triangle C h N C O L$ & $?$ & -0.289 & -0.70 \\
\hline$\Delta C h S T I$ & $?$ & $-0.416^{* * *}$ & -3.05 \\
\hline$\triangle C h L T I$ & $?$ & $-0.165^{*}$ & -1.66 \\
\hline$\triangle C h F I N L$ & $?$ & -0.000 & -0.00 \\
\hline$B I G 4 * \triangle C h C O A$ & + & $0.196^{*}$ & 1.79 \\
\hline$B I G 4 * \triangle C h C O L$ & + & $0.361^{*}$ & 1.90 \\
\hline$B I G 4 * \triangle C h N C O A$ & + & $0.131^{* *}$ & 2.09 \\
\hline$B I G 4 * \triangle C h N C O L$ & + & 0.537 & 1.11 \\
\hline$B I G 4 * \Delta C h S T I$ & + & $0.319^{* *}$ & 2.22 \\
\hline$B I G 4^{*} \Delta C h L T I$ & + & 0.062 & 0.56 \\
\hline$B I G 4^{*} \Delta C h F I N L$ & + & 0.073 & 0.56 \\
\hline$C F O$ & + & $0.755^{* * *}$ & 7.08 \\
\hline$L E V$ & $?$ & 0.012 & 0.23 \\
\hline LOSS & $?$ & $-0.126^{* * *}$ & -8.10 \\
\hline LOGTA & + & $0.060^{* * *}$ & 5.96 \\
\hline Industry Indicator & $?$ & \multicolumn{2}{|c|}{ YES } \\
\hline Year Indicator & $?$ & \multicolumn{2}{|c|}{ YES } \\
\hline Adjusted $\mathrm{R}^{2}$ & & \multicolumn{2}{|c|}{$24.09 \%$} \\
\hline No. of Obs. & & \multicolumn{2}{|c|}{7,493} \\
\hline
\end{tabular}

This table reports the regression results of the effect of Big Four auditors on the persistence of individual accruals components, measured via the balance sheet approach. All statistics and significance levels are based on standard errors adjusted by a one-dimensional cluster at the firm level. All variables are defined in the appendix. Please note that *, **, and, *** indicate statistical significance at the $10 \%, 5 \%$, and $1 \%$ levels (twotailed), respectively.

Next, I re-estimate the regression in Table 4 using future cash flows $(F C F O)$ as a dependent variable to test whether a high-quality audit leads to higher accrual component predictability with less reliability regarding future cash flows from operations. The results are shown in Table 5.

As Table 5 indicates, I find consistently that the coefficients of the variable of $B I G 4 * \triangle C h C O A$ is positive and significant at the $5 \%$ level, suggesting that high-quality audits improve the reliability of accrual components with less reliability by reducing accrual measurement error through the collection and evaluation of more and better audit evidence using competence and professional judgment. I also find that the coefficients of $B I G 4^{*} \triangle C h N C O L$, $B I G 4^{*} \triangle C h S T I$, and $B I G 4^{*} \triangle C h F I N L$ are significant at the 1 or $10 \%$ level, suggesting that Big Four auditors are also effective in auditing accrual components with less managerial subjectivity or other accrual components. Furthermore, I find that the coefficients of the variables $\left(B I G 4^{*} \triangle C h C O L, B I G 4^{*} \triangle C h N C O A, B I G 4^{*} \triangle C h L T I\right)$ of the Big Four interaction term are positive but not significant. Overall, these results corroborate the findings shown in Table 4 that high-quality auditors provide superior assurance regarding balance sheet accrual components with less reliability. 
Table 5. Regression Results on the Effects of Audit Quality on the Future Cash Flow Predictability of Accrual Components

\begin{tabular}{|c|c|c|c|}
\hline \multirow{2}{*}{ Variable } & \multirow{2}{*}{ Expected sign } & \multicolumn{2}{|c|}{ Dependent Variable: $F C F O$} \\
\hline & & Coefficient & t-statistics \\
\hline Intercept & $?$ & $-0.439^{* * *}$ & -2.75 \\
\hline$B I G 4$ & $?$ & -0.002 & -0.58 \\
\hline$\triangle C h C O A$ & $?$ & $0.165^{* * *}$ & 2.88 \\
\hline$\triangle C h C O L$ & $?$ & $0.256^{* *}$ & 2.27 \\
\hline$\triangle C h N C O A$ & $?$ & -0.026 & -1.14 \\
\hline$\triangle C h N C O L$ & $?$ & $-0.374^{* * *}$ & -2.71 \\
\hline$\Delta C h S T I$ & $?$ & $-0.166^{* * *}$ & -2.79 \\
\hline$\Delta C h L T I$ & $?$ & $-0.078^{*}$ & -1.96 \\
\hline$\triangle C h F I N L$ & $?$ & -0.019 & -0.38 \\
\hline$B I G 4 * \triangle C h C O A$ & + & $0.181^{* *}$ & 2.44 \\
\hline$B I G 4 * \triangle C h C O L$ & + & 0.191 & 1.58 \\
\hline$B I G 4 * \triangle C h N C O A$ & + & 0.049 & 1.39 \\
\hline$B I G 4 * \triangle C h N C O L$ & + & $0.857^{* * *}$ & 2.72 \\
\hline$B I G 4 * \Delta C h S T I$ & + & $0.221^{* * *}$ & 3.04 \\
\hline$B I G 4^{*} \Delta C h L T I$ & + & 0.032 & 0.61 \\
\hline$B I G 4^{*} \Delta C h F I N L$ & + & $0.123^{*}$ & 1.67 \\
\hline$C F O$ & + & $0.525^{* * *}$ & 14.50 \\
\hline$L E V$ & $?$ & $-0.032^{* * *}$ & -3.04 \\
\hline LOSS & $?$ & $-0.035^{* * *}$ & -5.46 \\
\hline LOGTA & + & $0.020^{* * *}$ & 3.22 \\
\hline Industry Indicator & $?$ & \multicolumn{2}{|c|}{ YES } \\
\hline Year Indicator & $?$ & \multicolumn{2}{|c|}{ YES } \\
\hline Adjusted $\mathrm{R}^{2}$ & & \multicolumn{2}{|c|}{$22.67 \%$} \\
\hline No. of Obs. & & \multicolumn{2}{|c|}{7,493} \\
\hline
\end{tabular}

This table reports the regression results on the effect of Big Four auditors on the predictability of future cash flows of individual accrual components, measured via the balance sheet approach. All statistics and significance levels are based on standard errors adjusted by a onedimensional cluster at the firm level. All variables are defined in the appendix. Please note that *, **, and, *** indicate statistical significance at the $10 \%, 5 \%$, and $1 \%$ levels (two-tailed), respectively.

Taken together, these results indicate that Big Four auditors provide superior audit quality in audit areas such as accruals with less reliability (e.g., accounting estimates), where auditors are required to exercise more professional judgment, resulting in improved accrual reliability.

Next, I categorize seven individual accrual components into three groups according to level of managerial subjectivity. I then re-estimate the regression models in Tables 4 and 5. The results are presented in Table 6. Columns 3 and 4 in Table 6 report the regression results using FROA as a dependent variable. The coefficients of BIG4*HighSubjAccr and BIG4*LowSubjAccr are positive and significant at the 1 and 5\% levels, respectively. The coefficient of $B I G 4^{*}$ OtherAccr is positive but not statistically significant. Overall, those results suggest that a highquality (e.g., Big Four) audit significantly improves accrual reliability across accrual components. Columns 5 and 6 in Table 6 report the regression results using $F C F O$ as a dependent variable. All the coefficients of the BIG4*HighSubjAccr and BIG4*LowSubjAccr interaction terms, including BIG4*OtherAccr, are positive and statistically significant at the 1 or $5 \%$ level, supporting the results shown in Tables 4 and 5. 
Table 6. Regression Results on the Effects of Audit Quality on the Accrual Reliability in Terms of Accrual Persistence and Future Cash Flow Predictability

\begin{tabular}{|c|c|c|c|c|c|}
\hline \multirow{2}{*}{ Variable } & \multirow{2}{*}{ Expected sign } & \multicolumn{2}{|c|}{ Dependent Variable: $F R O A$} & \multicolumn{2}{|c|}{ Dependent Variable: $F C F O$} \\
\hline & & Coefficient & t-statistics & Coefficient & t-statistics \\
\hline Intercept & $?$ & $-1.528^{* * *}$ & -6.48 & $-0.487^{* * *}$ & -3.07 \\
\hline$B I G 4$ & $?$ & 0.007 & 0.92 & -0.002 & -0.52 \\
\hline HighSubjAccr & $?$ & $-0.152^{* * *}$ & -3.49 & 0.003 & 0.14 \\
\hline MedSubjAccr & $?$ & $-0.189^{*}$ & -1.88 & $-0.110^{* *}$ & -2.36 \\
\hline LowSubjAccr & $?$ & $-0.154^{*}$ & -1.84 & -0.004 & -0.12 \\
\hline BIG4*HighSubjAccr & + & $0.143^{* * *}$ & 2.58 & $0.080^{* *}$ & 2.53 \\
\hline BIG4*OtherAccr & + & 0.143 & 1.25 & $0.149^{* *}$ & 2.13 \\
\hline BIG4*LowSubjAccr & + & $0.214^{* *}$ & 2.35 & $0.137^{* * *}$ & 2.74 \\
\hline $\mathrm{CFO}$ & + & $0.662^{* * *}$ & 7.14 & $0.436^{* * *}$ & 11.82 \\
\hline$L E V$ & $?$ & -0.010 & -0.17 & $-0.065^{* * *}$ & -5.91 \\
\hline LOSS & $?$ & $-0.141^{* * *}$ & -9.74 & $-0.047^{* * *}$ & -8.43 \\
\hline LOGTA & + & $0.062^{* * *}$ & 6.23 & $0.023^{* * *}$ & 3.73 \\
\hline Industry Indicator & $?$ & \multicolumn{2}{|c|}{ YES } & \multicolumn{2}{|c|}{ YES } \\
\hline Year Indicator & $?$ & \multicolumn{2}{|c|}{ YES } & \multicolumn{2}{|c|}{ YES } \\
\hline Adjusted $\mathrm{R}^{2}$ & & \multicolumn{2}{|c|}{$23.03 \%$} & \multicolumn{2}{|c|}{$20.65 \%$} \\
\hline No. of Obs. & & \multicolumn{2}{|c|}{7,493} & \multicolumn{2}{|c|}{7,493} \\
\hline
\end{tabular}

This table reports the regression results of the effect of Big Four auditors on the persistence and predictability of future accrual cash flows, categorized into three groups by level of managerial subjectivity. All statistics and significance levels are based on standard errors adjusted by a one-dimensional cluster at the firm level. All variables are defined in the appendix. Please note that *, **, and, *** indicate statistical significance at the $10 \%, 5 \%$, and $1 \%$ levels (two-tailed), respectively.

\section{Additional Analyses}

\section{Endogeneity Issue in Auditor Selection}

As a sensitivity test, I consider the potential endogeneity issue regarding the role of high-quality auditors in accrual persistence or the predictability of future accrual cash flows in which firms with higher earnings persistence or cash flow predictability are more likely to select high-quality auditors. To control for this endogeneity problem, I employ a Heckman two-stage approach (Heckman, 1979). First, I obtain the Inverse Mills Ratio (IMR) from the first-stage of auditor selection. ${ }^{11}$ Then, I include the IMR in the second stage. The untabulated results show that the findings shown in Table 6 are unchanged.

\section{Aggregate Future Earnings and Accrual Persistence}

I also examine whether the potential association between long-term performance and accrual reliability suggests another inference regarding the role of high-quality auditing in the persistence of accruals, especially as noncurrent accruals with more accounting estimates reflect firms' long-term profitability and outlook more accurately than do working capital accruals. To test the sensitivity of my results, I re-estimate the regression models in Table 6 using aggregated future two or three-year-ahead earnings or cash flows as a dependent variable. The untabulated results with two-year $(\mathrm{N}=5,551)$ and three-year-ahead aggregate future earnings $(\mathrm{N}=6,586)$ show that the coefficients of BIG4*HighSubjAccr and BIG4*OtherAccr are positive and statistically significant at all levels and that the coefficient of $B I G 4^{*}$ LowSubjAccr is positive but statistically significant only when using two-year-ahead aggregate future earnings. The untabulated results with two-year-ahead aggregate future cash flows $(\mathrm{N}=6,586)$ show that the coefficients of $B I G 4^{*}$ HighSubjAccr and $B I G 4^{*}$ LowSubjAccr are positive and statistically significant at the $5 \%$ level and that the coefficient of $B I G 4^{*}$ OtherAccr is positive but not significant. When using three-year-ahead aggregate

\footnotetext{
${ }^{11}$ Following the literature (e.g., Chaney et al. 2004; Lawrence et al. 2011), I estimate the self-selection of auditors in order to obtain the inverse Mills ratio as follows:

$B I G 4_{i t}=\alpha_{0}+\alpha_{1} L_{0}$ ASSETS $_{i t}+\alpha_{2}$ ATURN $_{i t}+\alpha_{3}$ CURR $_{i t}+\alpha_{4} L E V_{i t}+\alpha_{5} R_{\text {ROA }}+\alpha_{6}$ ROALOSS $_{i t}+\varepsilon_{i}$,

where BIG4 equals 1 if the client hires a Big Four auditor (BIG4) and 0 otherwise; LOG_ASSETS is the natural logarithm of total assets; ATURN is the ratio of sales to total assets; $C U R R$ is current ratio, measured as current assets divided by current liabilities; $L E V$ is the ratio of total liabilities to total assets; ROA is return on assets, measured as net income divided by lagged average total assets; ROALOSS is ROA times LOSS, where LOSS is equal to 1 if net income is negative and 0 otherwise.
} 
future cash flows $(\mathrm{N}=5,551)$, I find that all coefficients of the three interaction terms are positive but not statistically significant. Overall, these results support the findings shown in Table 6.

\section{SUMMARY AND CONCLUSION}

This study documents the consequences of high-quality (e.g., Big Four) audits on accrual reliability. Amid the adoption of the IFRS and the shift to a new, "principles-based" financial reporting paradigm, accrual reliability, including more accounting estimates, is of increasing importance to regulators, stakeholders, and auditors. In this study, I expect that a high-quality audit produces higher accrual persistence and predictability regarding future cash flows by reducing accrual measurement error and thereby improving accrual reliability through the collection and evaluation of more and better audit evidence using professional judgment. As expected, I find that the accrual persistence and cash flow predictability of firms audited by Big Four auditors are higher than are those of firms audited by non-Big Four auditors. Overall, these results suggest that Big Four auditors are more effective in improving the reliability of balance sheet accrual components with intrinsically lower reliability as well as those with high reliability. As the shift towards a new financial reporting regime highlights the importance of auditing areas with more accounting estimates, my study provides new insights into the association between the reliability of accruals with more accounting estimates and external auditing.

Data availability: The data are publicly available from the sources identified in the paper.

\section{ACKNOWLEDGEMENT}

This work was supported by the Ministry of Education of the Republic of Korea and the National Research Foundation of Korea (NRF- 2014S1A5A8018069).

\section{AUTHOR BIOGRAPHY}

Jong Eun Lee is an associate professor at Business School, SungKyunKwan University, South Korea. He received his Ph.D. from Temple University. His research areas include audit quality, internal control, and corporate governance. E-mail: jelee2012@skku.edu

\section{REFERENCES}

Baron, N., T. Figueiredo, and W. Weidman, 2004, Criterion's accrual model identifies companies most and least likely to experience accounting class actions, Criterion Research Group LLC.

Barth, M. E., W. H. Beaver, J. R. M. Hand, and W. R. Landsman, 1999, Accruals, cash flows, and equity values, Review of Accounting Studies 4: 205-229.

Becker, C., M. DeFond, J. Jiambalvo, and K.R. Subramanyam, 1998. The effect of audit quality on earnings management, Contemporary Accounting Research 15, 1-24, Bernstein, L. 1993. Financial Statement Analysis. 5th cd. Homewood, IL: Irwm.

Chaney, P., D. Jeter, and L. Shivakumar, 2004, Self-selection of auditors and audit pricing in private firms, The Accounting Review 79, 51-72.

Choi, J.-H, C. Kim, J.B. Kim, and Y. Zhang, 2010, Audit office size, audit quality, and audit pricing, Auditing: A Journal of Practice and Theory 29, 73-98.

Christensen, B., S. Glover, and D.A. Wood, 2012, Extreme estimation uncertainty in fair value estimates: The implications on audit assurance, Auditing: A Journal of Practice and Theory 31 (1), 127-146.

Dechow, P., S. Kothari, and R. Watts, 1998, The relation between earnings and cash flows, Journal of Accounting and Economics 25, 133-168.

DeFond, M., 1992, The association between change in client firm agency costs and auditor switching, Auditing: A Journal of Practice and Theory 11, 16-31.

Dichev, I., 2008, On the balance sheet-based model of financial reporting, Accounting Horizons 22, 453-470.

Feroz, E., Park, K., and Pastena, V, 1991, The financial and market effects of the SEC's accounting and auditing enforcement releases, Journal of Accounting Research 29, 107-142.

Financial Accounting Standards Board (FASB), 1978, Statement of Financial Accounting Concepts No.1. Objectives of Financial Reporting by Business Enterprises, FASB, Norwalk, Conn. 
Francis, J., E. Maydew, and H. Sparks, 1999, The role of Big 6 auditors in the credible reporting of accruals, Auditing: A Journal of Practice and Theory 18, 17-34.

, and J. Krishnan, 1999, Accounting accruals and auditor reporting conservatism, Contemporary Accounting Research 16, 135-165.

Heckman, J. T., 1979, Sample selection bias as a specification error, Econometrica 47, 153-161.

International Auditing and Assurance Standard Board, 2008, Challenges in auditing fair value accounting estimates in the current market environment, Staff audit practice alert (October), IAASB, New York, N.Y.

Jamal, K., R. Bloomfield, T. Christensen, R. Colson, S. Moehrle, J. Ohlson, S. Penman, T. Stober, S. Sunder, and R. Watts, 2010 , A research-based perspective on the SEC's proposed rule - Roadmap for the potential use of financial statement prepared in accordance with International Financial Reporting System (IFRS) by U.S. issuers, Accounting Horizons 24, 139-147.

Kinney, W.R., Jr., 2001, Accounting scholarship: What is uniquely ours? The Accounting Review 72, 275-284.

Krishnan, G., 2003a, Audit quality and the pricing of discretionary accruals, Auditing: A Journal of Practical \& Theory 22, 109126.

,2003b, Does Big 6 auditor industry expertise constrain earnings management? Accounting Horizons 17, 1-16.

Lawrence, A., M. Minutti-Meza., and P. Zhang, 2011, Can Big 4 versus non-Big 4 differences in audit-quality proxies be attributed to client characteristics? The Accounting Review 86, 259-286.

Lev, B., S. Li., and T. Sougiannis, 2010, The usefulness of accounting estimates for predicting cash flows and earnings, Review of Accounting Studies 15, 779-807.

Levitt, A., 1998, The 'numbers game.' Speech at the N.Y.U. Center for Law and Business, New York, N.Y., September 28.

Palmrose, Z., 1988, An analysis of auditor litigation and audit service quality, Accounting Review 63, 55-73.

Petroni, K.R., and M. Beasley, 1996, Errors in accounting estimates and their relation to audit firm type, Journal of Accounting Research 34, 151-171.

Public Company Accounting Oversight Board (PCAOB), 2007, Remarks at the Compliance Week Annual Conference on Governance, Risk \& Compliance. June 7. Available at: http://pcaobus.org/News/Speech/Pages/06072007_Mark WOlsonRemarks.aspx.

,2007, Auditing Standard No. 5 (AS5): An Audit of Internal Control Over Reporting That Is Integrated with Audit of Financial Statements and Related Independence Rule and Conforming Amendments. Washington, DC: PCAOB. http://pcaobus.org/Standards/Auditing/Pages/Auditing_Standard_5.aspx

2008, Audit considerations in the current economic environment, Staff audit practice alert No. 3. Washington D.C.: PCAOB.

,2010, Audit considerations of litigation and other contingencies arising from mortgage and other loan activities, Staff audit practice alert No. 7. Washington D.C.: PCAOB.

Ramos, M.J., 1998, Auditing Estimates and Other Soft Accounting Information. New York, NY: American Institute of Certified Public Accountants.

Richardson, S., R. Sloan, M. Soliman, and I. Tuna, 2005, Accrual reliability, earnings persistence and stock prices, Journal of Accounting and Economics 39, 437-485.

Schipper, K. 2003, Principles-based accounting standards, Accounting Horizons 17, 61-72.

Securities and Exchange Commission, 2003, Study Pursuant to Section 108(d) of the Sarbanes-Oxley Act of 2002 on the Adoption by the United States Financial Reporting System of a Principles-Based Accounting System. Submitted to Committee on Banking, Housing, and Urban Affairs of the U.S. Senate and Committee on Financial Service of the U.S. House of Representativeness. Washington, D. C.: Government Printing Office.

Simunic, D.A., and M.T. Stein, 1987, Product differentiation in auditing: Auditor choice in the market for unseasoned new issues, Canadian Certified General Accountants Research Foundation, Vancouver, BC.

Sloan, R.G., 1996, Do stock prices fully reflect information in accruals and cash flows about future earnings? The Accounting Review 71, 289-315.

St. Pierre, K. and J. Andersson, 1984, An analysis of the factors associated with lawsuits against public accountants, Accounting Review 59, 242-263.

White, H. 1980, A heteroskedasticity-consistent covariance matrix estimator and a direct test for heteroscedasticity, Econometrica 48, 817-838. 


\section{APPENDIX}

\section{Summary of Variable Measurements}

\begin{tabular}{|c|c|}
\hline Variable & Variable Definition \\
\hline TACC & Measured as $(\triangle C O A-\triangle C O L+\triangle N C O A-\triangle N C O L+\triangle S T I+\triangle L T I-\triangle F I N L)$, deflated by average total assets. \\
\hline$\triangle C O A$ & $\begin{array}{l}\text { Change in Current Operating Assets, measured as } \Delta \text { (Current Assets-Cash and Short-Term Investments), } \\
\text { deflated by average total assets. }\end{array}$ \\
\hline$\triangle C O L$ & $\begin{array}{l}\text { Change in Current Operating Liabilities, measured as } \Delta \text { (Current Liabilities-Debt in Current Liabilities), } \\
\text { deflated by average total assets. }\end{array}$ \\
\hline$\triangle N C O A$ & $\begin{array}{l}\text { Change in Non-current Operating Assets, measured as } \Delta \text { (Total Assets-Current Assets-Investments and } \\
\text { Advances), deflated by average total assets. }\end{array}$ \\
\hline$\triangle N C O L$ & $\begin{array}{l}\text { Change in Non-current Operating Liabilities, measured as } \Delta \text { (Total Liabilities-Current Liabilities-Long- } \\
\text { Term Debt), deflated by average total assets. }\end{array}$ \\
\hline$\Delta S T I$ & Change in Short-term Investment, deflated by average total assets. \\
\hline$\Delta L T I$ & Change in Long-term Investment, deflated by average total assets. \\
\hline$\triangle F I N L$ & $\begin{array}{l}\text { Change in Financial Liabilities, measured as } \Delta \text { (Long-term Debt + Debt in Current Liabilities + Preferred } \\
\text { Stock), deflated by average total assets. }\end{array}$ \\
\hline HighSubjAccr & $\begin{array}{l}\text { The sum of Change in Current Operating Assets }(\triangle C O A) \text { and Change in Non-current Operating Assets } \\
(\triangle N C O A) \text {, deflated by average total assets. }\end{array}$ \\
\hline LowSubjAccr & $\begin{array}{l}\text { The sum of minus Change in Current Operating Liabilities }(\triangle C O L) \text { and Change in Short-term } \\
\text { Investment }(\Delta S T I) \text { and minus Change in Financial Liabilities }(\triangle F I N L) \text {, deflated by average total assets. }\end{array}$ \\
\hline OtherAccr & $\begin{array}{l}\text { The sum of minus Change in Non-current Operating Liabilities }(\triangle N C O L) \text { and Change in Long-term } \\
\text { Investment }(\Delta L T I) \text {, deflated by average total assets. }\end{array}$ \\
\hline$B I G 4$ & 1 if an external auditor is a Big Four auditor and 0 otherwise. \\
\hline CFO & Cash flow from operations deflated by average total assets. \\
\hline FROA & One-year-ahead $R O A$, measured as net income divided by average total assets. \\
\hline$F C F O$ & One-year-ahead $C F O$, deflated by average total assets. \\
\hline$L E V$ & Firm's leverage ratio, measured as total liabilities deflated by total assets. \\
\hline LOSS & 1 if the net income is negative and 0 otherwise. \\
\hline LOGTA & Natural logarithm of total assets (AT). \\
\hline
\end{tabular}

